\title{
Assessment of diesel degrading potential of fungal and bacterial isolates from Egypt
}

\section{Mohesien MT*, El-Morsy EM and Abou-Dobara MI}

Department of Botany and Microbiology, Faculty of Science, Damietta University, New Damietta, Egypt.

Mohesien MT, El-Morsy EM and Abou-Dobara 2018 - Assesment of diesel degrading potential of fungal and bacterial isolates from Egypt. Microbial Biosystems 3(2), 1-12.

\begin{abstract}
Two naturally occurring fungal and bacterial species, Aspergillus flavus and Bacillus sp. H6 strains, were capable of utilizing diesel oil as a sole source of carbon in synthetic microcosoms. The initial diesel oil contamination of $1666 \mathrm{mg} \mathrm{kg}^{-1}$ dry soil was reduced to $166.667 \mathrm{mg} \mathrm{kg}^{-1}$ after 150 days of incubation in fungal-bacterial consortium microcosm. That is mean $89.9 \%$, of the initial oil concentration was removed. Abiotic process reduced the diesel oil contamination to about $616 \mathrm{mg} \mathrm{kg}^{-1}$ dry soil at the end of the experiment. Seven microcosms were set up to fulfill the experiments. The decontamination activity follow this order; Bacillus sp. $\mathrm{H} 6+$ A. flavus consortium $>$ Bacillus sp. $\mathrm{H} 6>$ natural control $>$ A. flavus $>$ cycloheximide treated $>$ benzyl Penicillin-Streptomycin treated > poisoned control. Gas chromatographic analysis data revealed that both A. flavus and Bacillus sp. H6 treatment led to complete utilization of carbon-17 compounds. Other biodegradation products such as C-15, 16, 20, 21, and 24 appears in the chromatogram after 150 days incubation. Increase of C-20, 21 and C-24 compounds also noticed. The fungal- and bacterium consortium treatment depicted a decrease of all detected n-alkanes. The microbial success in biodegradation was evaluated by determining the number of germinating seeds of Phaseolus vulgaris. The highest level of germination (92\%) was detected in consortium microcosms after 150 days incubation. The treatment with $A$. flavus and Bacillus sp. H6 separately led to a lower percentage of germination (86\%). The other treatments showed variable results except the poisoned control that showed negative germination and minor chemical degradation of diesel oil. Thus, bacterial-fungal consortium treatment is effective in bioremediation of contaminated oils than separate treatment.
\end{abstract}

Key words - Diesel, biodegradation, Aspergillus flavus, Bacillus sp. H6.

\section{Introduction}

Diesel oil is one of the major contaminants of soil and groundwater. This is almost due to industrial wastes and oil spill accidents. Consequently, littoral marshes ecosystems and other coastal entertainment are known to severely damage from the impacts of large amounts of noxious compounds, especially petroleum oil spills (Mille et al. 1998; Teal et al. 1992; Duke and Watkinson 2002).

Several methods can be used to remove hydrocarbons from soil and groundwater, including air spraying, soil vapor extraction, and bioremediation. Strategies for inexpensive and clean in situ bioremediation include natural attenuation, biostimulation, bioventing, bioaugmentation, land farming, composting, and phytoremediation. These methods can be reviewed in numerous publications reporting on the bioremediation diesel oil (Richard and 
Vogel 1999; Olson et al. 1999; Gallego et al. 2001; Bento et al. 2004; EL-Morsy 2005; ELMorsy et al. 2006) in soils.

Many isolated bacterial and fungal species have been reported to be capable of effectively in biodegradion of petroleum hydrocarbons and even polynuclear aromatic hydrocarbons (Giraud et al. 2001; Márquez-Rocha et al. 2005; Xiaojun et al. 2008; You-Qing et al. 2008). Petroleum products contain a mixture of several hydrocarbons, which are difficult to degrade by any one bacterium. Short-chain alkanes are toxic to many microorganisms and are difficult to degrade. Intermediate chain lengths (C10-C24) are degraded most rapidly. Very long chain alkanes become increasingly resistant to biodegradation. Monoxygenases and dioxygenases are a group of the enzymes involved in the degradation of alkanes. The aromatic hydrocarbons present in petroleum are also difficult to degrade.

Bioremediation is being used or proposed as a treatment option at many hydrocarboncontaminated sites (Braddock et al. 1997). The effectiveness of bioremediation is often a function of the microbial population or consortium and how it can be enriched and maintained in an environment (Márquez-Rocha et al. 2001). The ability of fungi to transform a wide variety of hazardous chemicals has aroused interest in using them in bioremediation (Alexander 1994). Biodegradation of oil spills is a major problem because it usually occurs in marine water surface and seeding with bacteria becomes difficult.

It is well known that very few organisms are able to degrade a single compound completely. Degradation of organic compounds in the natural environments is often the result of a community-interacting microbial population, generally termed as a 'consortium'. Fungi and bacteria have been shown to biodegrade organic pollutants via both non-enzymatic and enzymatic processes. Therefore, a synergistic effect is expected in the biodegradation by simultaneous use of bacteria and fungi. Chávez-Gómez et al. (2003) stated that several fungal and bacterial co-cultures exhibited synergism for phenanthrene removal, reaching about $70 \%$ in 18 days. Likely, You-Qing et al. (2008) found a significant synergistic effect between Cladosporium and Mycobacterium resulted in approximate complete degradation (99\%) of diesel oil. However, Xiaojun et al. (2008) stated that microbial consortia could degrade polycyclic aromatic hydrocarbons (PAHs), but the highest PAH removals were detected by fungi only.

In Egypt, attention has been devoted to the application of crude oil degrading microorganisms in the bioremediation of crude oil spills left at the end of 1967 war in Suez Gulf area (Ammar et al. 1997; Ammar and Shady 2001). The aim of this work is to bioremediate the diesel contaminated soil by using Aspergillus flavus and Bacillus sp. H6.

\section{Materials and Methods}

\subsection{Soil microcosm's processes}

\subsubsection{Selected species}

Aspergillus flavus and Bacillus sp. H6 were selected for bioremediation study based up on their abundance and lipolytic activities (EL-Morsy et al. 2006).

\subsubsection{Microcosms preparation}

Soils from the coastal beaches of New Damietta were collected. The soils are sandy and alkaline ( $\mathrm{pH}$ 8.8), with organic matter content of $5.9 \%$, and total nitrogen of $0.21 \%$ and an available phosphate content of $24.8 \%$. The soil $(0-10 \mathrm{~cm}$ depth) was collected cleaned from wood drafts soil crustaceous skeleton, and sieved at $0.02 \mathrm{~mm}$ sieve. The soil for laboratory experiments was dried at $80{ }^{\circ} \mathrm{C}$ overnight (this may serve to eliminate indigenous bacteria from the soil). Once dried, About $10 \mathrm{~kg}$ of soil was selected for use, sprinkled with $0.166 \mathrm{~g}$ diesel oil/g dry soil until form a very thin layer of oil over the soil and left for 7 days. After adsorption of diesel, the humidity was approximately $43 \%$. The $\mathrm{pH}$ was adjusted to 7.5-7.8 and to avoid any acidic shift in $\mathrm{pH}$ the soil was limed with $2 \mathrm{~g} \mathrm{CaCO}_{3} / \mathrm{kg}$ dry soil. The nitrogen level was also adjusted to $150 \mathrm{ug} / \mathrm{g}$ soil. Ratio of oil: N: P was 100: 10: 1 . After thorough mixing, about $2 \mathrm{~kg}$ of 
soil was placed into each of seven microcosms. Each microcosm consisted of plastic box (length, $25 \mathrm{~cm}$; width, 15; depth, 15). The water content was adjusted regularly to $60 \%$ water retention capacity. The seven microcosms were set up as follow. The microcosms M1, M2 and M3 were amended with Bacillus sp. H6 (6.1 x 105 / g dry soil), Aspergillus flavus (6.1 x 105 / g dry soil), and a consortium of Bacillus sp. H6 plus A. flavus (6.1 x $105 / \mathrm{g}$ dry soil) respectively. The fourth (M4) was a natural control microcosm without any treatment. The fifth microcosm (M5) was sterilized by addition of fungicide (cycloheximide $75 \mathrm{mg} / \mathrm{kg}$ ) antibiotic. The third (M6) microcosm was weekly treated with bactericide (benzyl Penicillin G, $37.5 \mathrm{mg} / \mathrm{kg}$; Streptomycin, $37.5 \mathrm{mg} / \mathrm{kg})$. A poison control (M7) made by monthly addition of $\mathrm{AgNO}_{3}(0.3 \%$ $\mathrm{W} / \mathrm{W})$. The experiment has been done in triplicate. Sampling was done immediately after the microcosms were set up and at regular intervals of $15 \mathrm{~d}$ and through out a 5 month at $28 \pm 2^{\circ} \mathrm{C}$. The soil in the microcosms was thoroughly mixed, and approximately 5-g samples, equally distributed, were taken from each box. Samples were analyzed in triplicate.

\subsection{Hydrocarbon biodegradation}

Total petroleum hydrocarbons (TPH) were measured in ten grams of soil. The soil dehydrated with Na2SO4 and mixed for $30 \mathrm{~min}$ with $10 \mathrm{ml}$ of 1, 1, 2-trichlorotrifluoroethane; the TPH content of the filtrate was quantified as described in (American Public Health Association 1985).

\subsection{Gas chromatography}

$5 \mathrm{~g}$ of soil were extracted twice with $50 \mathrm{ml}$ of dichloromethane. The organic phase was passed through $\mathrm{NaSO}_{4}$ and concentrated to $0.2 \mathrm{ml}$ and then analyzed by gas chromatography (GC 17-A, Shimadza - Jaban model) equipped with the fame ionization detector and capillary column. The column oven found at $60{ }^{\circ} \mathrm{C}$, which rise to $270{ }^{\circ} \mathrm{C}$ by $7{ }^{\circ} \mathrm{C}$ at 10 minutes. The injections temperature $280{ }^{\circ} \mathrm{C}$, the detector (FID) temperature $300{ }^{\circ} \mathrm{C}$ and the injections volume is 1 micro millimeters. Peaks from 5 to 35 minutes were used for total diesel determination in all experiments.

\subsection{Germination of plants}

Known weight of bioremediation soil $(10 \mathrm{~g})$ was mixed with fifteen seeds of Phaseolus vulgaris in pots. The plants were irrigated with water and the germination of the seeds was examined daily for a week. The results were taken in duplicates.

\section{Results}

\subsection{Bioremediation}

Figure 1 demonstrates the effect of different treatments on hydrocarbon removal for a period of 150 days and at $28 \pm 2{ }^{\circ} \mathrm{C}$. The initial activity was variable and the decontamination activities are low after 15 and 30 days in all microcosms. The initial oil concentration $1666 \mathrm{mg} /$ $\mathrm{kg}$ dry soil was reduced to 633.33, 800, 166.667, 633.33, 1100, 830 and $850 \mathrm{mg} / \mathrm{kg}$ dry soil, in Bacillus sp. H6, A. flavus, Bacillus sp. H6 + A. flavus, natural control, cycloheximide-treated, streptomycin-benzyl penicillin treated and poisoned control microcosms after 150 days, respectively. More than 1000 mg hydrocarbons were eliminated after 105 days in the microcosm that contains Bacillus sp. H6 plus A. flavus. Moreover, biodegradation by Bacillus sp. H6 plus A. flavus was reached to $166.7 \mathrm{mg} / \mathrm{kg}$ dry soil of the added oil after 150 days incubation. About 50 $\%$ of the oil added was removed in the bacterial less microcosms. 


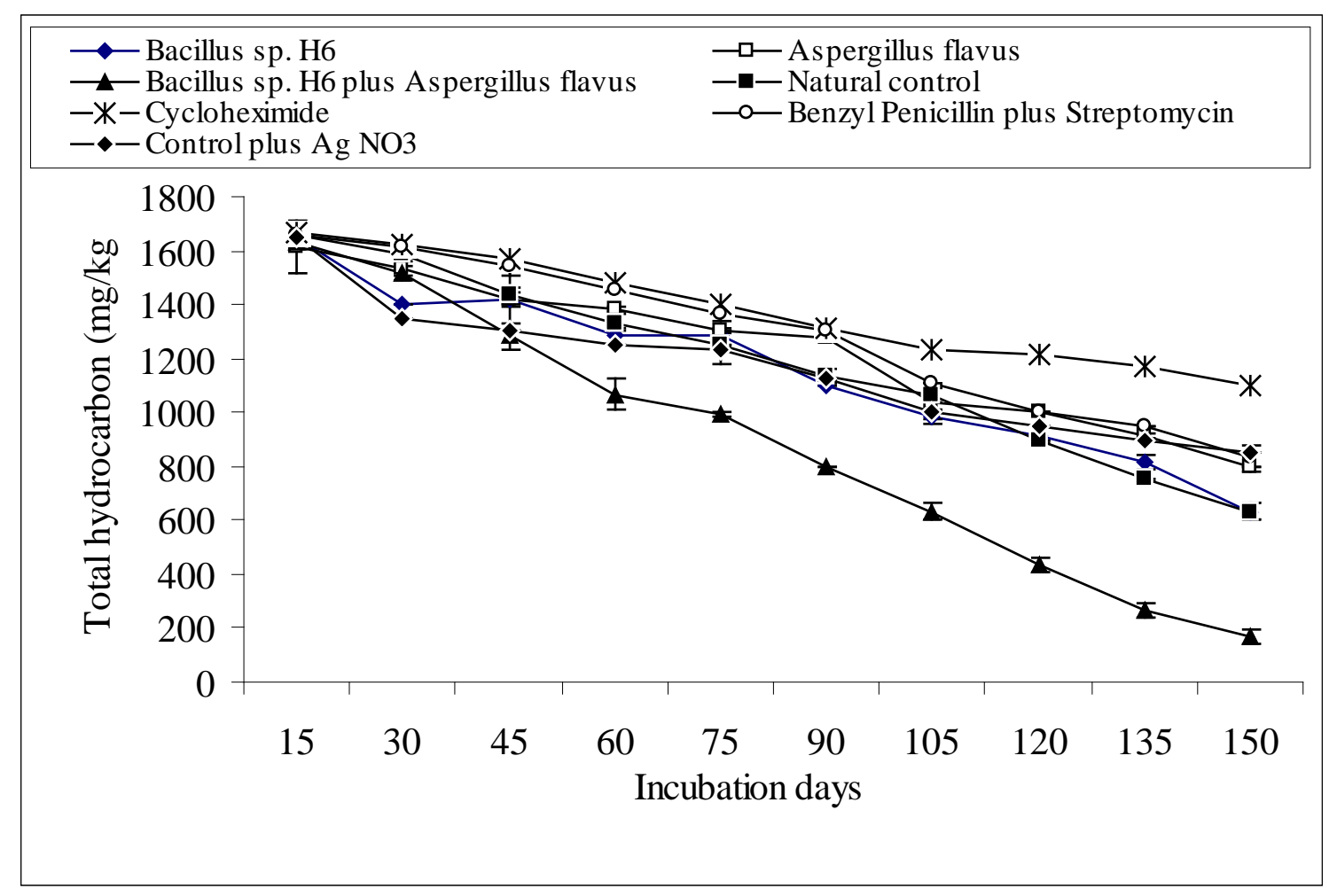

Fig. 1- Biodegradation of diesel oil incubated in soil microcosms at $28 \pm 2{ }^{\circ} \mathrm{C}$.

\subsection{Gas chromatography analysis}

The gas chromatography analyses of biodegraded diesel oil were illustrated in chromatograms of figs. 2 to 8 . The chromatographic data produced in this analysis is separated in several peaks. Fig. $2 \mathrm{~b}$ to $8 \mathrm{~b}$, representing residual diesel after 150 days (end of the biodegradation study) depict changes. Fig. 2a to 8a representing diesel at the start point. Figure 2 revealed that before inoculation with $A$. flavus and after 150 days incubation, meian chain $\mathrm{C}-17$ compound was completely eliminated and other biodegradable compounds (C-20, C-21 and C24) would increase. Alike, Fig. 3 demonstrated the appearance of C-15 and C-16 biodegradation product, before inoculation with Bacillus sp. $\mathrm{H6}$ and after 150 days of incubation. It also confirmed the elimination of C-17 and increase of C-20, C-21 and C-24 biodegradation carbon product. Moreover, Fig. 4 illustrated the decrease of all detected n-alkanes that detected before inoculation with Bacillus sp. H6 and Aspergillus flavus. Likely, Fig. 5 demonstrated that soil with indigenous microfungi showed a low consuming rate of C-17, 18, 20 and C-24 compounds. Whereas Fig. 6 showed a prominent elimination of C-15, C-16, and C-17, besides the release of more C-20, C-21 and C-24 biodegradation product, in soil with indigenous bacteria. Furthermore, GC analyses in Fig. 7 demonstrated also the induction of more C-17, C-18, C-19, C-20, C-21 and C-24 biodegradation products, in natural soil microcosm, before and after 150 days of incubation. Conversely, in poisoned microcosm the oil was degraded chemically as appear in Fig. 8. 

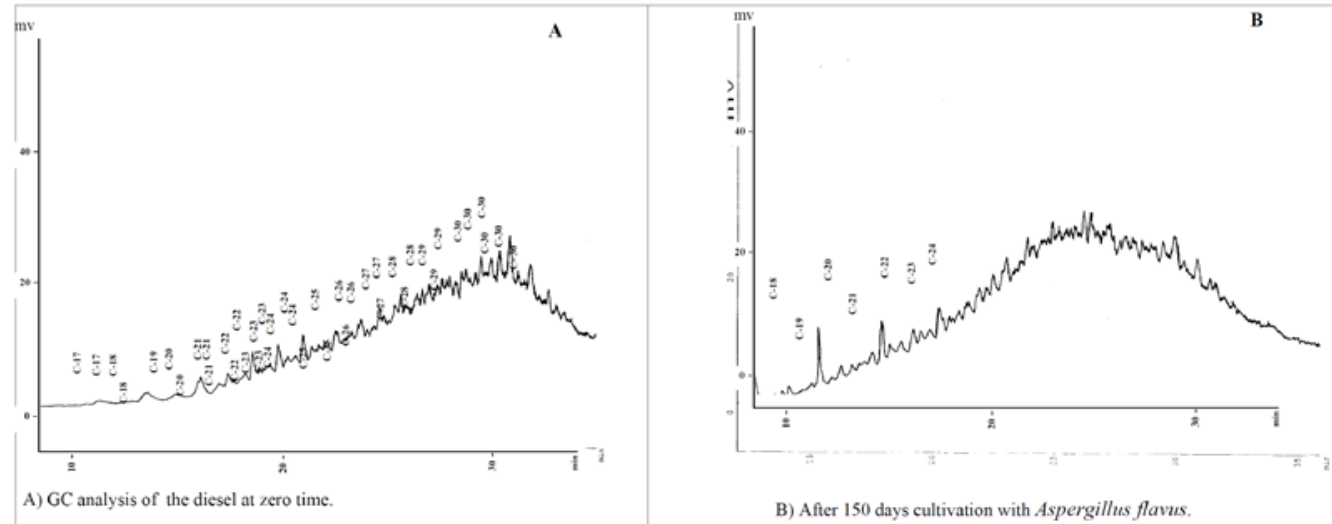

B) After 150 days cultivation with Aspergillus flavus.

Fig. 2- Gas chromatography (GC) analyses of the remainder diesel when Aspergillus flavus was grown in the microcosm.

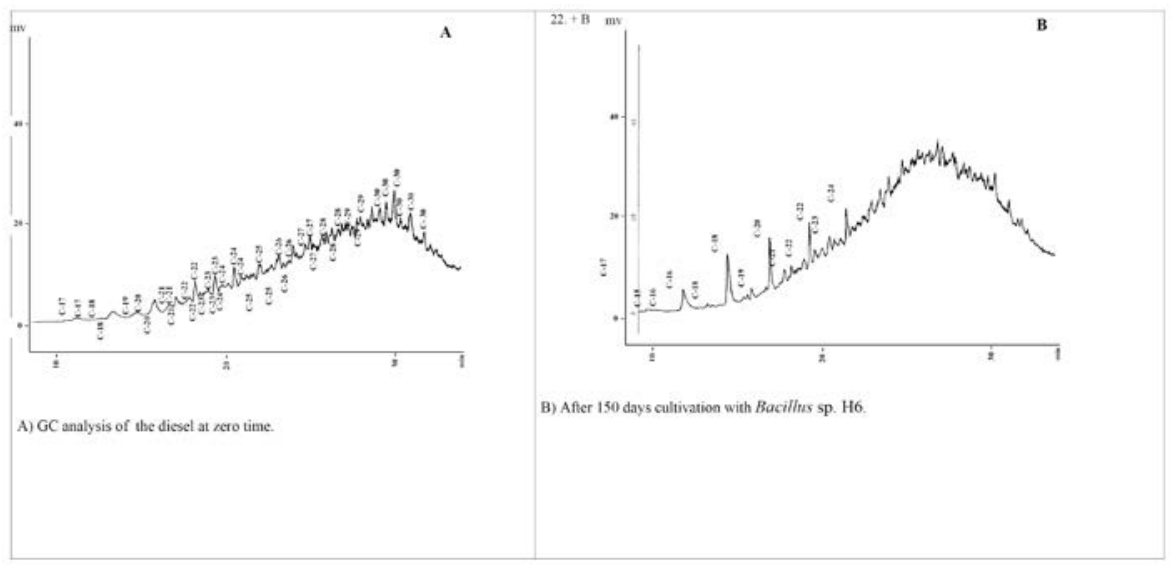

Fig. 3- Gas chromatography (GC) analyses of the remainder diesel when Bacillus sp. H6 was grown in the microcosm.

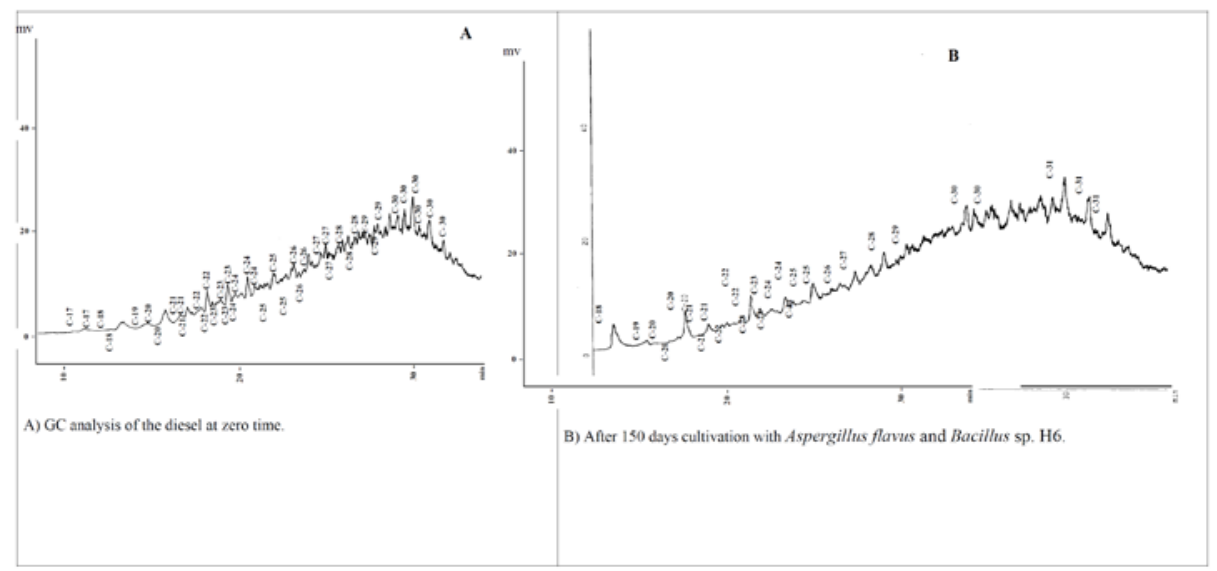

Fig. 4- Gas chromatography (GC) analyses of the remainder diesel when Aspergillus flavus and Bacillus sp. H6 were grown in the microcosm. 


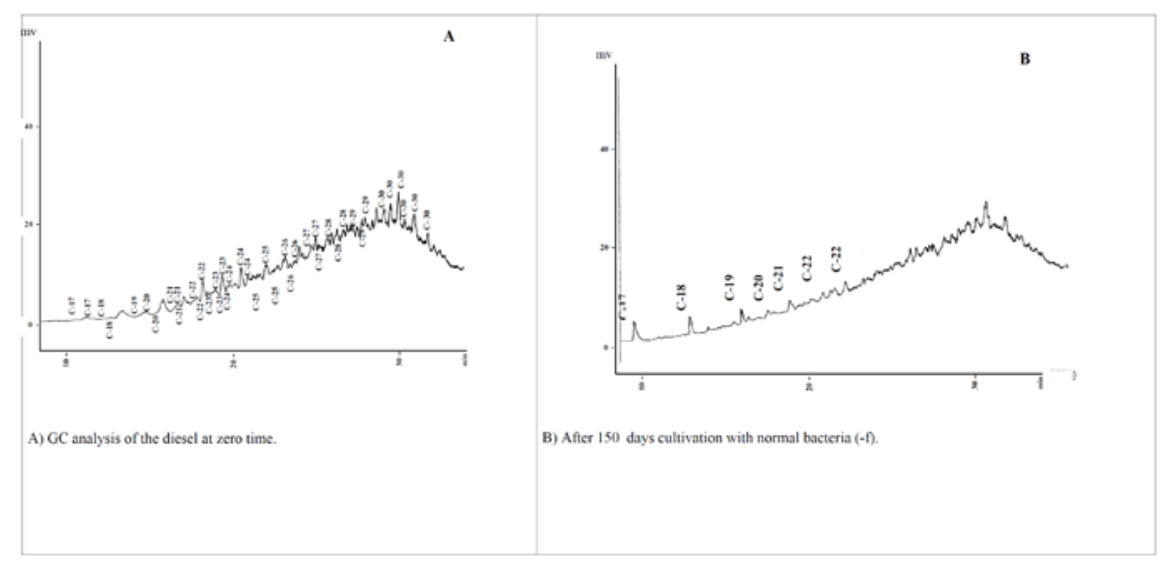

Fig. 5- GC analyses of the remainder diesel when normal bacteria were growing in the microcosm.

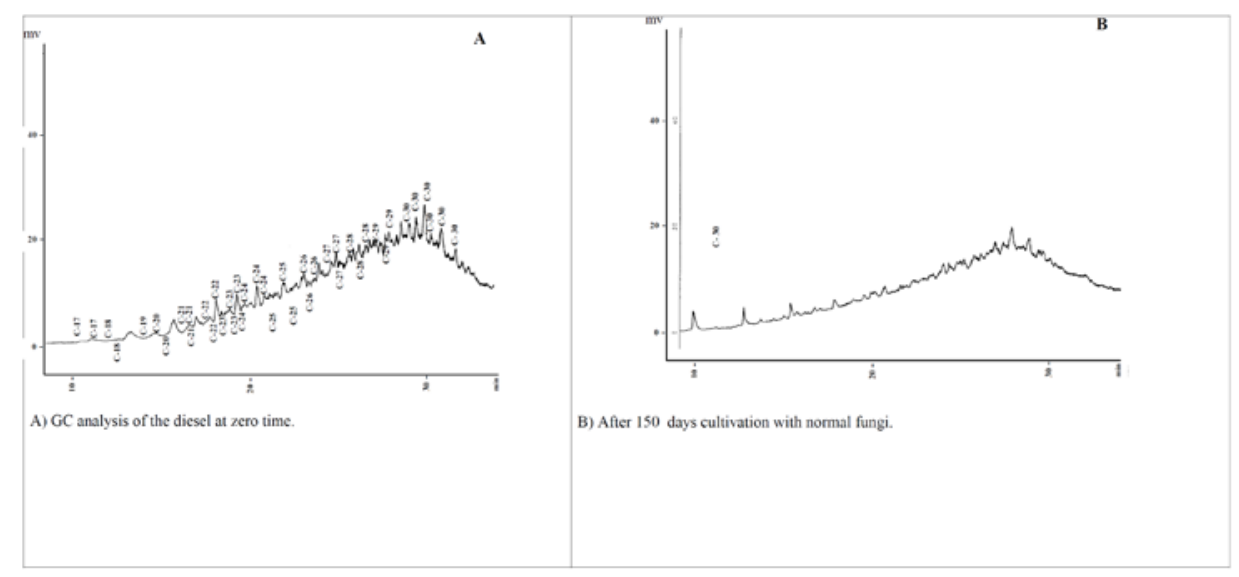

Fig. 6- GC analyses of the remainder diesel when normal fungi were growing in the microcosm.

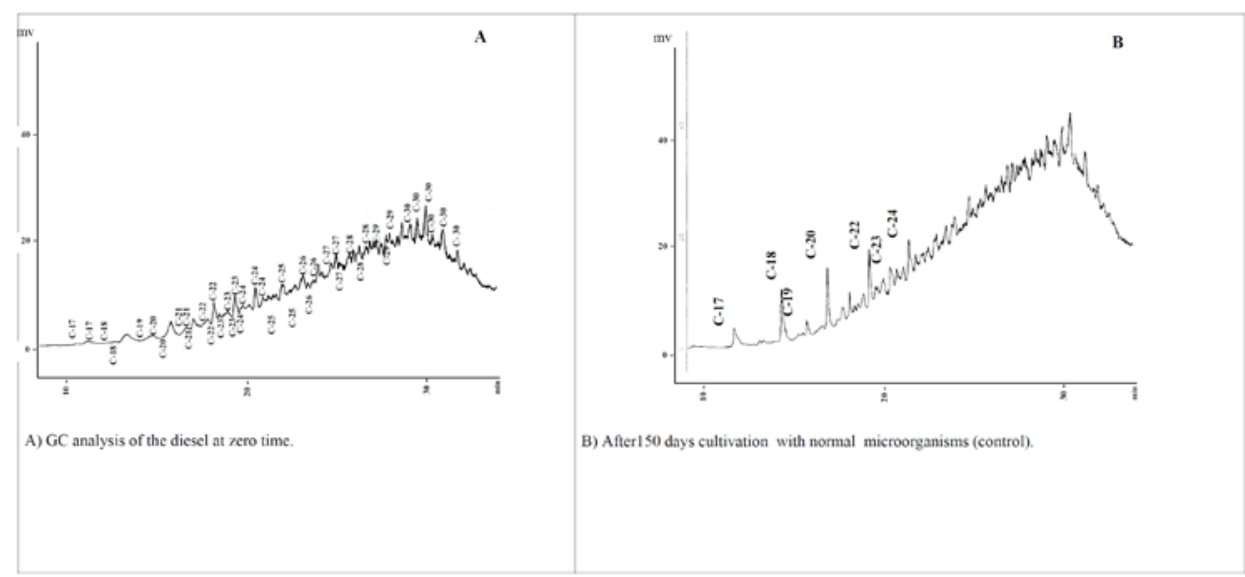

Fig. 7- GC analyses of the remainder diesel when normal microorganisms (control) were grown in the microcosm. 


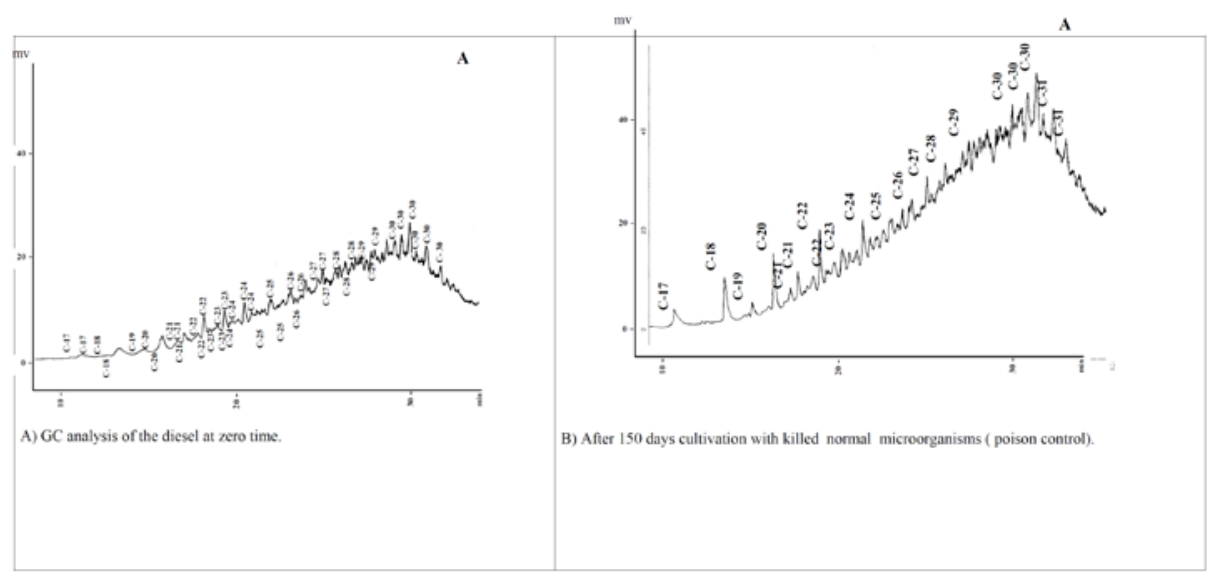

Fig. 8- GC analyses of the remainder diesel when all normal microorganisms were killed (poison control) in the microcosm.

\subsection{Germination test}

The results in figure 9 illustrated that the percentage of germinating seeds increases with incubation time in soil collected from all microcosms except poisoned one. At the beginning of the experiment the percentage of the germination is very low. The highest level of germination was detected after 150 days incubation (92 \%) consorium microcosms (M3). whereas, the treatment with A. flavus and Bacillus sp. H6 separately led to a lower percentage of germination (86\%) at the end of the experiment. Analogously antibacterial (M6), antifungal (M5) treated and natural (M4) microcosms have good percentage of seed germination of $73 \%, 66 \%$ and $60 \%$ respectively, after 150 days incubation. Conversely, in the poisoned treatment, seed germination was completely absent.

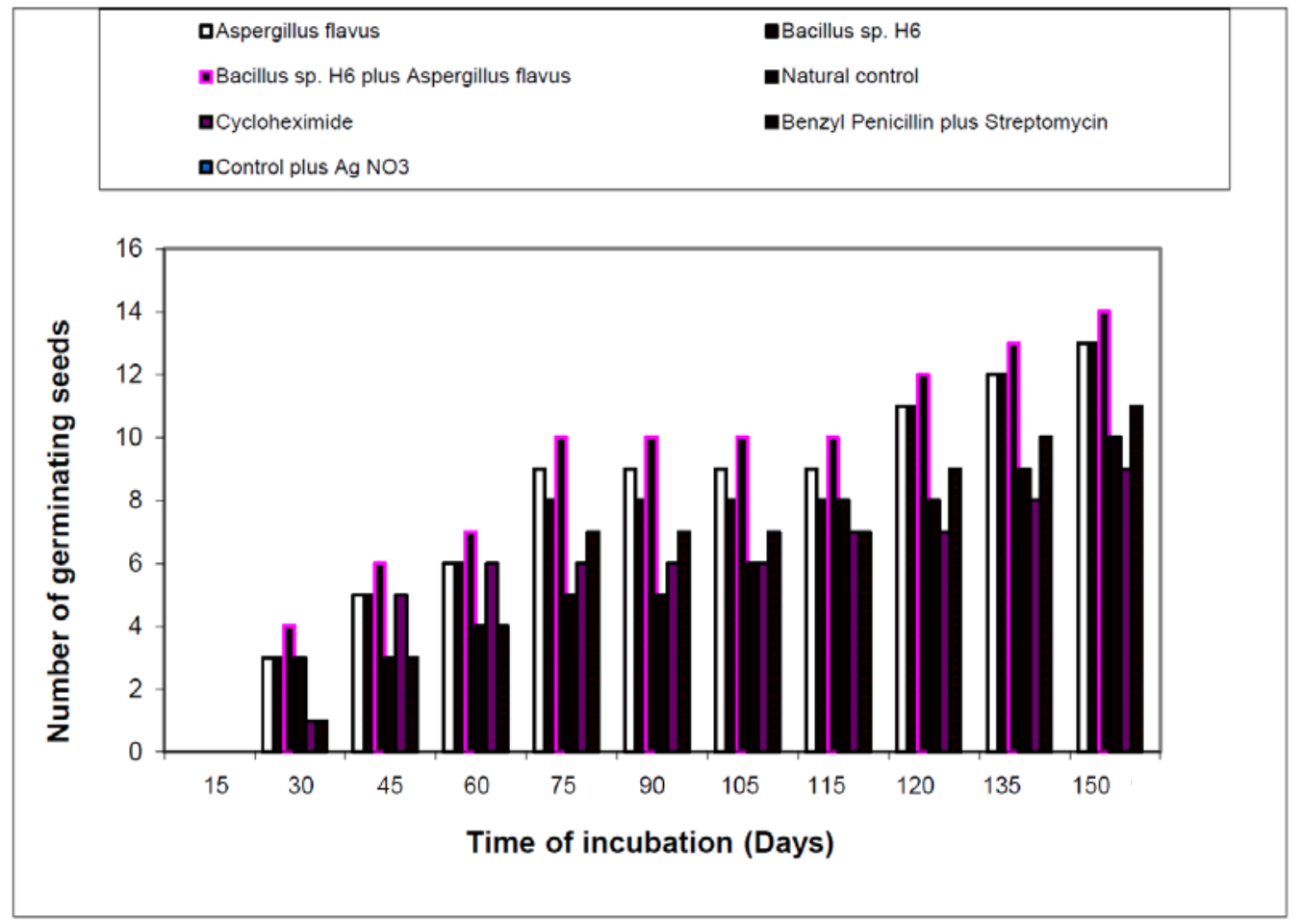

Fig. 9- Effect of different treated soils on the germination of the Phaseolus vulgaris seeds through out the whole experiments. 


\section{Discussion}

The cultures, A. flavus and Bacillus sp. H6, in separate or in consortium demonstrated very good n-alkane degradation characteristics and could simultaneously degrade n-alkanes with a wide range of carbon numbers. As observed in this study, good degradation of the n-alkane fraction in various types of oil is often reported in the literature. Olson et al. (1999) reported 75\% loss for the n-alkane fraction of total extractable petroleum hydrocarbons in diesel oil after 35 days in batch flask experiments.

Diesel oil consists mostly of linear and branched alkanes with different chain lengths and contains a variety of aromatic compounds. Many of these compounds, especially linear alkanes, are known to be easily biodegradable. However, diesel oil has low water solubility and so their biodegradation is limited by slow rate of dissolution, desorption, or transport and also transport processes to the cell (Márquez-Rocha et al. 2001; Sticher et al. 1997). Moreover, both biotic and abiotic processes are dependent on the chemical structure of the substrate to be degraded. In our experiment, diesel biodegradation does not appear to be limited by metabolic capabilities of the used bacterium, since that long chain alkanes ( $>$ C12) were biodegraded after bacterial growth. It seems to be limited due to mass transfer in bacteria, whereas fungi are better adapted because they grew well through soil particles.

Fungi are seemed to play a major role in biodegradation of aromatic compounds in soil. In this respect, Xiaojun et al. (2008) used three microbial consortia (bacteria, fungi and bacteriafungi complex) and stated that they could degrade polycyclic aromatic hydrocarbons (PAHs), and the highest PAH removals were found in soil and slurry inoculated with fungi $(50.1 \%$ and $55.4 \%$, respectively. Moreover, Cladosporium was found to be strongly biodegraded diesel oil with a real degradation ratio of up to 34\% after 5 days treatment (You-Qing et al. 2008). When the culture of Cladosporium was used with Mycobacterium hyalinum this led to a significant synergistic effect between them resulted in almost complete degradation of diesel oil, achieving a total diesel removal of $99 \%$ over 5 days of treatment. Comparable, it is reported that after 13 and 50 days of treatment with bacterium, all of the n-alkanes were degraded in the culture inoculated with the consortium of Pseudomonas and the major identified residues consisted of branched chain alkanes like pristane and phytane. It is also reported that no aromatic compounds were detected at the end of the experiment (Richard and Vogel 1999; Márquez-Rosha et al. 2001).

Generally, different microorganisms exhibit different abilities to degrade hydrocarbons. Some microorganisms can effectively degrade aliphatic alkanes, some have strong ability to degrade aromatic hydrocarbons, and some can degrade both aliphatic alkanes and aromatic hydrocarbons (Atlas 1995). The maximum decontamination activity occurred in the treatment of Bacillus sp. $\mathrm{H} 6$ and A. flavus is corresponding to $89.9 \%$. Alike, Bacillus sp. $\mathrm{H} 6$ has a decontamination rate corresponding to $61.9 \%$. In the same order, A. flavus has a decontamination activities corresponding to $51.9 \%$. A. flavus was found to be the most active fungus in degradation of oil in soil microcosms (EL-Morsy 2005).

The rate and extent of biodegradation was interpreted based on the GC chromatograms for residual diesel. The resolved n-alkane peaks in the diesel chromatograms were found to be in the carbon number range C15-C31. The fungus and bacterium either separately or in synergistic pattern act are consuming the carbon 17 compound in their metabolism and their biodegradation activity led to release of other short carbon compound such as C-15, C-16, C-20, C-21 and C-24. Ward et al. (2003) reported maximum degradation rate $(\mathrm{mg} / \mathrm{h})$ inversely related to chain length for C8-C11, in crude oil for mixed and pure cultures. Consequently, A. flavus alone can degrade both aliphatic hydrocarbons and aromatic hydrocarbons in diesel, though the degradation ability is not so strong. When the Bacillus sp. is mixed with A. flavus, the latter degrades aromatic hydrocarbons in diesel oil, permitting better growth of the former. Correspondingly, You-Qing et al. (2008) stated that the diesel biodegradation is significantly promoted by the mixed strains, 
resulting in the observed synergistic effect. He deduced that, degradation of aromatic hydrocarbons by Cladosporium favors the growth of Mycobacterium, enhancing the degradation of saturated hydrocarbons in diesel that promotes in turn the degradation of aromatic hydrocarbons by Cladosporium, increasing greatly the bioavailability of diesel oil. Alike, Sharma and Rehman (2009) stated bacterial consortium degraded long chain hydrocarbon into short chain one and so it is the better option for biodegradation of diesel oil in soil.

In the natural control, the decontamination rate is similar to the treatment of Bacillus sp. H6. Other treatments, however, had low decontamination activities. In cycloheximide and the streptomycin-benzyl penicillin treated microcosms the decontamination activities were corresponding to $33.9 \%$ and 49.8, respectively and this can be attributed to that the fungal activities of removal of the pollutant is higher than that of the bacterial activities. Conversely, poison control showed a decontamination activity. This abiotic loss of hydrocarbons in poisoned microcosm could be evaluated as a result of physical processes, as adsorption on soil particles and to evaporation of the volatile diesel oil fractions (Atlas and Bartha 1992; Bragg et al. 1994; Margesin and Schinner 1997). Additionally, it is observed that the hydrocarbon content cannot be reduced to zero and always reduction obtained was between 10 to $30 \%$ (Chaineau et al. 1995; Gro $\beta$ et al. 1995; Hollerbach et al. 1992; Margesin and Schinner 1997). Even when the incubation was prolonged; the reduction was slightly increased (Chaineau et al. 1995; Groß et al. 1995). This could be due to low bioavailability of the contaminant, the accumulation of recalcitrant components and inhibiting metabolites, and to the lack of microbial growth factors. Conversely, You-Qing et al. (2008) deduced that it is quite possible to achieve a complete degradation of diesel oil by appropriately increasing the degradation time.

The measured gas chromatograms of the diesel oil samples biodegraded was illustrated in figures from 2 to 8 . From the figures it is obvious that, the degradation treatment caused a uniform decrease of the GC peaks, indicating that all of the components in diesel oil, including both saturated hydrocarbons and aromatic hydrocarbons, were significantly degraded at almost the same degradation rate. This strongly supports the above explanation. Moreover, Fig. 4B shows low level of residual diesel oil after a 150-day treatment.

The effects of the above treatments on the availability of oil-contaminated soil for agriculture were obvious in Phaseolus vulgaris seed germination test. In facts, all treatments enhanced the rate of seed germination except the poisoned treated one. The rate increased from 0-germination before the treatment in all microcosms to $92 \%, 86 \%, 86 \%, 73 \%, 66 \%$ and 60 \% germination in soil collected from A. flavus-Bacillus sp. H6, A. flavus, Bacillus sp. H6, streptomycin benzyl-Penicillin, cycloheximide and natural treated microcosms respectively, at the end of the experiments. Silva et al. (2015) reported that diesel oil toxicity was found to be reduced after seven days in bioreactor trials where lettuce seeds (Lactuca sativa) and beans (Phaseolus vulgaris L.) showed germination rates of 41- $54 \%$, respectively. Also, Roy et al. (2014) observed that under microcosm, soil quality was improved significantly in the treatments of crude oil by bacterial consortium as confirmed by maximum increase in seedling dry weight for both rice (Oryza sativa) (54\%) and mung (Vigna radiata) (63\%). Likely, it was reported that oil pollution is a serious obstacle to photosynthesis where albinos seedlings of Avicennia marina have been observed with increasing oil concentration in sediments, some plants die, but others survive and have possible sub-lethal responses (Duke et al. 1997; Duke and Watkinson 2002). It is obvious that the concentration of oil used was toxic to the seeds and raising their germination rate progressively with increasing incubation period may be attributed to the microbial biodegradation of diesel oil to non toxic intermediates and other changes in soil physicochemical properties (Atlas 1981; Leahy and Colwell 1990; Banks et al. 2000). 


\section{Conclusion}

Based on the present work, the following conclusions could be drawn: the rate and extent of diesel biodegradation was significantly increased by using fungal and nacterial consortium. Diesel pollutants in soil microcosms could be almost completely removed (89\%) by the synergistic effect of Bacillus sp. H6 and A. flavus. The chemical tolerance of the microorganisms is very essential for achieving highly efficient degradation of organic pollutants when the mixed microorganism consortium is used. Thus, these microorganisms can be used effectively in the treatment of oil polluted areas.

\section{Conflict of Interest}

The authors do not have any conflicts of interest.

\section{Acknowledgements}

The authors are deeply thanks the Damietta and Mansoura Universities for supporting and funding this investigation.

\section{References}

Alexander M. 1994. Bioremediation technologies. In Biodegradation and Bioremediation. Academic Press, London, New York, pp. 248-271.

American Public Health Association, American Water Works Association and Water Pollution Control Federation 1985. Standard Methods for the Examination of Water and Waste Water. American Public Health Association Office, 1015 Fifteenth st. NW Washington, DC 20005.

Ammar M .S. and Shady E. A. 2001. Biotechnological bioremediation of oil spills for more clean Egyptian environments. Proceeding of the 3rd International Conference for environmental management and technologies, 29-31 October, p. 738-768.

Ammar M. S., Tantawy H. and Shady E. A. 1997. In situ application of biotechnology for the clean up of crude oil spills in Suez Gulf area of Egypt. 8th European Congr. On Biotechnology, 17-21 Aug. Ann. Rev. Microbiol., 19: 183-208.

Atlas R. M. 1981. Microbial degradation of petroleum hydrocarbon: An environmental perspective. Microbiol. Rev., 45: 180-20.

Atlas R. M. 1995. Petroleum biodegradation and oil spill bioremediation. Marine Pollution Bulletin, 31: 178-182.

Atlas R. M. and Bartha R. 1992. Hydrocarbon biodegradation and oil spill bioremediation. Adv. Microb. Ecol., 12: 287-338.

Banks M. K., Govindaraju R. S., Schwab A. P. and Kulakow P. 2000. Part I: Field demonstration, pp. 3-88. In: Phytoremediation of hydrocarbon-contaminated soil, Fiorenza, S., C.L. Oubre and C.H. ward (eds.), Baton Rouge, Lewis Publication.

Bento F. M., Camargo F. A. O., Okeke B. C. and Frankenberger W. T. Jr. 2004. Bioremediation of diesel oil. Braz. J. Microbiol., 27: 65-68.

Braddock J. F., Ruth M. L., Catterall P. H., Walworth J. L. and Mccarthy K. A. 1997. Enhancement and inhibition of microbial activity in hydrocarbon-contaminated arctic soils: Implications for nutrient-amended bioremediation. Environ. Sci. Techno., 31(7): 2078.

Bragg J. R., Prince R. C., Harner E. J. and Atlas R. M. 1994. Effectiveness of bioremediation for the Exxon Valdez oil spill. Nature, 368: 413-418.

Chaineau C. H., Morel J. L. and Oudot J. 1995. Microbial degradation in soil microcosms of fuel oil hydrocarbons from drilling cuttings. Environ. Sci. Technol., 29: 1615-1621. 
Chávez-Gómez B., Quintero R. and Esparza-García F. 2003. Removal of phenanthrene from soil by co-cultures of bacteria and fungi pregrown on sugarcane bagasse pith. Bioresour Technol, 89: 177-183.

Duke N. C. and Watkinson A. J. 2002. Chlorophyll-deficient propagules of Avicennia marina and apparent longer-term deterioration of mangrove tress in oil-polluted sediments. Marine pollution Bulletin, 44: 1269-1276.

Duke N. C., Pinzon Z. S. and Prada M. C. 1997. Large-scale damage to mangrove forests following two large oil spills in Panama. Biotropica, 29: 2-14.

El-Morsy E. M. 2005. Evaluation of soil microfungi for the bioremedetiation of diesel oil in Egypt. Land contamination and reclamation, 13: 147-159.

El-Morsy E. M., Abou-Dobara M. I. and Mohesien M. T. 2006. Quantitative assessment of oildegrading microorganisms from coastal Mediterranean soil of Egypt. Assiut Univ J. of Botany. 35 (1):223-244.

Gallego J. R., Loredo J. E., Llamas F., Vazquez F. and Sanchez J. 2001. Bioremediation of Diesel-Contaminated Soils: Evaluation of potential in situ techniques by study of bacterial degradation. Biodegradation, 12: 325-335.

Giraud F., Guiraud P. and Kadri M. 2001. Biodegradation of anthracene and fluoranthene by fungi isolated from an experimental constructed wetland for wastewater treatment. Wat Res, 35: 4126-4136.

Gro $\beta$ A., Schepp R. and Kaltwasser H. 1995. Untersuchungen zur optimierung des mikrobiellen olabbaues im Böden. In: EV Dechema ed. P. 72-73. Dechema-Jahrestagungen '95. Band II Umwelttechnik, Frankfurt/M.

Hollerbach A., Ripper P., Rippen G. and Friedrich L. 1992. Kritische anmerkungen zur beurteilung des kohlenwasserstoffgehaltes in Böden mittels DIN 38409 H17 und H18. In: Bewertung und Sanierung mineralöl-kontaminierter Böden. P. 565-573. Dechema, Frankfurt / M.

Leahy J. G. and Colwell R. R. 1990. Microbial degradation of hydrocarbons in the environment. Microbiological Reviews, 54: 305-315.

Margesin R. and Schinner F. 1997. Bioremediation of diesel-oil contaminated alpine soils at low temperatures. Appl. Microbiol. Biotechnol., 47: 462-468.

Márquez-Rocha F. J., Olmos-Soto J. and Rosano-Hernández M. C. 2005. Determination of the hydrocarbon-degrading metabolic capabilities of tropical bacterial isolates. International Biodeterioration and Biodegradation, 55: 17-23.

Márquez-Rocha F. J., Hernández-Rodríguez V. and Lamela M. T. 2001. Biodegradtion of diesel oil in soil by a microbial consortium. Water, Air and Soil Pollution, 128: 313-320.

Mille G., Munoz D., Jacquot F., Rivet L. and Bertrand J. C. 1998. The Amoco Cadiz oil spill: evolution of petroleum hydrocarbons in the I1e Grande salt marshes (Brittany) after a 13year period. Estuarine, Coastal and Shelf Science, 47: 547-559.

Olson J. J., Mills G. L., Herbert B. E. and Morris P. J. 1999. Biodegradation rates of separated diesel components. Int. Toxic. Chem., 18: 2448-2458.

Richard J.Y. and Vogel T. M. 1999. Characterization of a soil bacterial consortium capable of degrading diesel fuel. International Biodeterioration and Biodegradation, 44: 93-100.

Roy A. S., Baruah R., Borah M., Singh A. K., Boruah H. P. D., Saikia N., Deka M., Dutta N. and Bora T. C. 2014. Bioremediation potential of native hydrocarbon degrading bacterial strains in crude oil contaminated soil under microcosm study. International Biodeterioration and Biodegradation, 94: 79-89.

Sharma A. and Rehman M. B. 2009. Laboratory scale bioremediation of diesel hydrocarbon in soil by indigenous bacterium consortium. Indian Journal of Experimental Biology, 47: 766-769. 
Silva D. P., Cavalcanti D., de Melo E. J. V., dos Santos P. N. F., da Luz E. L. P., de Gusmäo N. B. and de Queiroz Sousa M. 2015. Bio-removal of diesel oil through a microbial consortium isolated from a polluted environment. International Biodeterioration and Biodegradation, 97: 85-89.

Sticher P., Jaspers M. C., Stemmler K., Harms H., Zehnder A. J., and van der Meer J. R. 1997. Development and characterization of a whole-cell bioluminescent sensor for bioavailable middle-chain alkanes in contaminated groundwater samples. Applied and Environmental microbiology, 63(10):4053-60.

Teal J. M., Farrington J. W., Burns K. A., Stegeman J. J., Tripp B. W., Woodin B. and Phinney C. 1992. The West Falmouth Oil Spill after 20 years: Fate of fuel oil compounds and effects on animals. Marine Pollution Bulletin, 24: 607-614.

Ward O., Singh A., Van Hamme J. 2003. Accelerated biodegradation of petroleum hydrocarbon waste. Journal of Industrial Microbiology and Biotechnology, 30: 260-270.

Xiaojun L. , Peijun L., Xin L., Chungui Z., Qi L. and Zongqiang G. 2008. Biodegradation of aged polycyclic aromatic hydrocarbons (PAHs) by microbial consortia in soil and slurry phases. Journal of Hazardous Materials, 150: 21-26

You-Qing L., Hong-Fang L., Zhen-Le T., Li-Hua Z., Ying-Hui W. and He-Qing T. (2008). Diesel Pollution Biodegradation: Synergetic effect of Mycobacterium and filamentous Fungi 1. Biomedical and Environmental Sciences, 21:181-187. 